\title{
Erratum to: Imaging in the Diagnosis and Treatment of Endometrial Cancer
}

\author{
Jessica J. Kraeft and Susanna I. Lee
}

\section{Erratum to:}

\section{Chapter "Imaging in the Diagnosis and Treatment}

of Endometrial Cancer" in:

J. J. Kraeft, S. I. Lee, Current Clinical Oncology, DOI 10.1007/7631_2015_3

\section{Page 1}

Abstract: 'recurrence' should be 'recurrences'.

\section{Section "Introduction"}

$\left(1^{\text {st }}\right.$ paragraph $), 5^{\text {th }}$ line: hyphen missing in 'post-treatment'.

Page 2

Section "Cancer Detection"

(First paragraph), $3^{\text {rd }}$ line: Deleted 'because'.

\section{Page 3}

Section "Endometrial Morphology"

$\left(1^{\text {st }}\right.$ paragraph $), 6^{\text {th }}$ line: deleted 'nonfocal'.

Page 4

Section “Cancer Staging”

( $1^{\text {st }}$ paragraph): Replaced 'because of the' with 'due to'.

( $2^{\text {nd }}$ paragraph $), 9^{\text {th }}$ line: deleted 'case'.

( $3^{\text {rd }}$ paragraph), $9^{\text {th }}$ line: Inserted 'invasion' 
Page 6

Section "Sonohysterography"

( $4^{\text {th }}$ paragraph)

$5^{\text {th }}$ line: Replaced 'Because' with 'As'. Inserted 'a' after 'demonstrates'

$8^{\text {th }}$ line: Replaced 'for' with 'in'.

\section{Page 7}

Section “Magnetic Resonance Imaging”, last line: ‘. . .with TVUS or biopsy is precluded.' was replaced with '.. is precluded with TVUS or biopsy.'

Section "Technique" ( $1^{\text {st }}$ paragraph $), 14^{\text {th }}$ line: inserted 'may' after 'cancer'. Changed 'presents' to 'present'.

Section “Cancer Detection" $\left(1^{\text {st }}\right.$ paragraph $), 6^{\text {th }}$ line: Inserted 'as' after 'appears'.

Page 8

Section "Cancer Staging" ( $1^{\text {st }}$ paragraph):

Throughout this section "MR" has been corrected to "MRI".

$1^{\text {st }}$ line: Insert 'The' at beginning of sentence.

$3^{\text {rd }}$ line: insert 'patients' after 'those'. Revise 'stage' with 'stages'.

$6^{\text {th }}$ line: Delete 'lymph node'

$7^{\text {th }}$ line: Replace 'on those' with 'in patients'.

$8^{\text {th }}$ line: Replace 'extrauterine metastases' with 'lymph'.

$23^{\text {rd }}$ line: Replace 'for' with in'. Replace 'diagnosis' with diagnosing'.

$\left(2^{\text {nd }}\right.$ paragraph), line 1: Replace 'Because' with “As”.

Section “Myometrial Invasion”: ( $2^{\text {nd }}$ paragraph)

$1^{\text {st }}$ line: Replaced 'are' with 'occur'.

$2^{\text {nd }}$ line: Replaced 'to' with 'of'

$8^{\text {th }}$ line: Revised 'demonstrates' to 'demonstrate'

Section “Cervical Invasion”: ( ${ }^{\text {st }}$ paragraph): Delete the last sentence.

( $2^{\text {nd }}$ paragraph):

$1^{\text {st }}$ line: Replace 'of up to' with 'using MRI are reported to be as high as'.

$2^{\text {nd }}$ line: Delete 'reported'. Replace 'because' with 'as'.

Page 9

Fig. 6: In caption 'with surgical pathology' was replaced with 'by pathologic examination'.

Fig.7.: In caption 'with surgical pathology' was replaced with 'by pathologic examination'.

Section “Extrauterine Spread': (1 ${ }^{\text {st }}$ paragraph), lines 3-4: 'into parametrial fat' was replaced with 'to serosa'.

Page 10

Fig. 8: In caption "with surgical evaluation and' was replace with 'by pathologic examination'.

Page 11

Fig. 9: In caption 'on surgical pathology' was replaced with ' by pathologic examination'.

Section 'Computed Tomography': ( $1^{\text {st }}$ paragraph):

$8^{\text {th }}$ line: 'whose' was replaced with 'with a'. 
$13^{\text {th }}$ line: 'In detecting lymphadenopathy' was moved to $14^{\text {th }}$ line after word 'MRI'.

$16^{\text {th }}$ line: 'for a lymph node to be' was inserted after the word 'diameter'.

$18^{\text {th }}$ line: 'detecting' was inserted before word 'lymph'.

$\left(2^{\text {nd }}\right.$ paragraph $)$

$10^{\text {th }}$ line: 'For detecting cervical invasion' was replaced with 'in detecting myometrial invasion,' $13^{\text {th }}$ line: 'in detecting cervical invasion' was inserted after 'specifity'.

Page 14

Fig. 12: In caption 'pathologically' was deleted. At end of caption 'and pathologic evaluation' was inserted.

Section 'Imaging Post-primary Therapy': (1 $1^{\text {st }}$ paragraph), $4^{\text {th }}$ line: 'for recurrent tumor' and 'the' were deleted.

Section 'Conclusion': $7^{\text {th }}$ line: 'made' was replaced with 'confirmed'.

Page 15

Fig. 13: In caption 'pathologically' was deleted. 